\title{
Expression of melatonin receptors in triple negative breast cancer (TNBC) in African American and Caucasian women: relation to survival
}

\author{
Gabriela Oprea-Ilies • Erhard Haus • Linda Sackett-Lundeen • \\ Yuan Liu - Lauren McLendon · Robert Busch • \\ Amy Adams $\cdot$ Cynthia Cohen
}

Received: 29 July 2012/Accepted: 3 December 2012/Published online: 19 December 2012

(C) The Author(s) 2012. This article is published with open access at Springerlink.com

\begin{abstract}
In the normal rodent breast, the pineal hormone melatonin controls the development of ductal and alveolar tissue. Melatonin counteracts tumor occurrence and tumor cell progression in vivo and in vitro in animal and human breast cancer cell cultures. It acts predominantly through its melatonin MT1 receptor. Our aim was to investigate the presence or absence of the MT1 melatonin receptor in the aggressive triple negative group of human breast carcinoma (TNBC) and its possible relationship to the course of the disease. A total of 167 patients with a ER-, PR-, Her2/neu- phenotype in which tissue for receptor studies was available were examined. The MT1 receptor immunostain was evaluated semiquantitatively as staining intensity $(0,1$, 2,3 ), percentage of stained cells and the weighted index
\end{abstract}

G. Oprea-Ilies $(\bowtie)$

Department of Pathology, Emory University School

of Medicine, Emory University and Winship Cancer Institute,

1364 Clinton Road, NE, Atlanta, GA 30322, USA

e-mail: goprea@emory.edu

E. Haus

Department of Lab Medicine and Pathology, University

of Minnesota, Minneapolis, MN, USA

e-mail: Erhard.X.Haus@HealthPartners.com

E. Haus

HealthPartners Institute for Education and Research,

Minneapolis, MN, USA

E. Haus · L. Sackett-Lundeen

Department of Pathology, Regions Hospital,

640 Jackson Street, St. Paul, MN 55101, USA

e-mail: Linda.L.SackettLundeen@HealthPartners.com

Y. Liu

Biostatistics and Bioinformatics Department,

Winship Cancer Institute, Atlanta, GA 30322, USA

e-mail: yliu31@emory.edu
(WI) (staining intensity times percentage of stained cells). A score of WI $<60$ was regarded as "negative". There was a striking difference in incidence of MT1 positivity and staining intensity between carcinomas in African American (AA) and Caucasian (C) women. The AA showed a higher incidence of MT1 negative tumors (41/ $84=48.8 \%$ in $\mathrm{AA}, 6 / 51=11.8 \%$ in C) and a lower average WI. MT1 positivity in TNBC was associated with a lower stage and a smaller tumor size at time of diagnosis. In multivariable survival analysis, MT1 negative TNBC in all cases regardless of race showed a significantly higher hazard ratio for disease progression, shorter progression free survival, and disease-related death, and shorter OS. This was especially pronounced in the AA group but did

\section{McLendon}

Department of Surgery, Emory University School of Medicine, 1364 Clifton Road NE, Room H120, NE, Atlanta,

GA 30322, USA

e-mail: lamclen@emory.edu

R. Busch

Fellowship Training Program, Division of Pulmonary and Critical Care Medicine, Harvard Pulmonary and Critical Care Medicine, 55 Fruit St BUL-148, Boston, MA 02114, USA e-mail: rbusch@partners.org

\section{A. Adams}

Department of Pathology, Emory University Hospital H185A, Emory University School of Medicine, 1364 Clifton Road NE, Atlanta, GA 30322, USA

e-mail: aladam2@emory.edu

\section{Cohen}

Anatomic Pathology, Department of Pathology, G144A EUH, Emory University School of Medicine, 1364 Clifton Road NE, Atlanta, GA 30322, USA

e-mail: ccohe01@emory.edu 
not reach statistical significance in the smaller group of $\mathrm{C}$ alone. These results suggest that melatonin or a melatonin receptor agonist may be useful biologic additions in the treatment of some forms of TNBC, especially in AA who generally show a more aggressive course of their disease.

Keywords Melatonin receptor MT1 - Triple negative breast cancer - Racial disparity · African American . Breast cancer

\section{Introduction}

Melatonin is the main secretory product of the pineal gland. It is secreted in a high amplitude circadian periodic pattern, the timing of which is determined by the environmental light-dark regimen $[1,2]$. Melatonin acts both through non-receptor-dependent anti-oxidative and receptor-dependent mechanisms. Two types of G-protein-bound specific high affinity receptors (MT1 and MT2) are described [3-5].

In addition to effects upon the endocrine and immune systems, melatonin exerts, via the MT1 receptor, direct regulatory actions on cell proliferation [4]. In the normal rodent breast, melatonin controls the development of ductal and alveolar tissue [6], and counteracts tumor occurrence and tumor cell proliferation in vivo and in vitro (e.g., Hill et al. [6]; Blask et al. [7]). Anti-proliferative actions of melatonin on human and animal tumor cell lines and in animal models have been reported for breast cancer $[6,8-$ 10], prostate cancer [11, 12], colon cancer [13], some but not all ovarian cancers [14], endometrial cancer [15], liver cancer (hepatoma 7288 CTC) [16], pancreatic cancer [17], malignant melanoma [18-20], oral squamous cell carcinoma [21], and glioma cells [22].

The oncostatic and anti-invasive actions of melatonin and of melatonin receptor agonists [23] are mediated via the MT1 melatonin receptor [6], are enhanced by MT1 receptor overexpression [6, 24], and are inhibited by luzindole, a MT1 inhibitor [6]. In physiologic concentration, melatonin suppresses the growth of both estrogen receptor alpha (ER $\alpha$ )-positive (MCF-7, T47D, ZR 75-1) and some ER $\alpha$-negative (MDA-MB-468) human breast cancer cell lines in vitro. The proliferation of other ER $\alpha$-negative cell lines (MDA-MB-231, MDA-MB-336, and BT-20) is not inhibited by melatonin $[6,8,25]$.

In some studies, the expression of the MT1 receptor correlated positively with the expression of the ER $\alpha$ receptor [26]. By way of activating its MT1 receptor, melatonin can suppress the development of cancer via a broad spectrum of mechanisms with and without involvement of $\mathrm{ER} \alpha$ [6]. In rodents, melatonin in vivo inhibits the development and growth of both carcinogen-induced [27, 28] and spontaneously developing [29, 30] mammary tumors acting through melatonin receptor-mediated mechanisms [31, 32].

The development of specific antibodies [33] allowed the study of MT1 receptors in histologic sections of human breast and breast carcinomas [26, 34]. With immunohistochemistry, MT1 cytoplasmic activity is expressed in benign luminal breast epithelial cells. The receptor was absent or weak in ducts and acini in $68 \%$ of cases. In contrast, moderate to strong reactivity was seen in most (75\%) of the cases of ductal carcinoma in situ (DCIS) and invasive ductal carcinoma (IDC). In the available studies, no mention was made of the triple negative phenotype of breast cancer.

The triple negative variant of human breast cancer (TNBC) (ER-, PR-, HER2/neu-) includes several different molecular patterns and different phenotypes with varying expression of basal and luminal markers [35-37], and differences in course and outcome [37, 38]. There are differences between ethnic groups with a higher incidence and more aggressive course in AA women [39] and in Hispanic women [40]. The MT1 receptor status in TNBC is at this time unknown. The use of melatonin as supportive treatment of breast cancer has been suggested on the basis of preclinical data $[7,9,41]$ and several small clinical trials [42-46], none including the triple negative phenotype. There is presently no targeted biologic treatment for these tumors as is available for ER-positive and HER2-positive cancers. If subgroups of TNBC with high MT1 activity can be identified, the possibility exists that melatonin can be added to the usual chemotherapy. The goal of this study is to identify the presence or absence of the MT1 melatonin receptor in TNBC in African American (AA) and Caucasian (C) women, and to explore clinical correlations between clinicopathologic parameters, cancer markers and the course of the disease with the expression of MT1.

\section{Methods}

With Investigation Review Board (IRB) approval, the surgical pathology files for 2003 to 2008 at Emory University and Grady Memorial Hospitals (Atlanta, Georgia) were searched for breast carcinomas that did not immunostain for ER, and PR and which were scored as $0,1+$, or $2+$ immunohistochemically (IHC), with fluorescent in situ hybridization (FISH) as non-amplified HER2. A total of 167 TNBC were identified in which formalin fixed paraffin embedded (FFPE) tissue for MT1 receptor studies was available. Of these, 84 were AA and $53 \mathrm{C}$ women. Since not all variables were available in all women, the numbers in some tables are different. The population statistics of the $\mathrm{AA}$ and $\mathrm{C}$ women are summarized in Table 1. An additional group of five subjects were of Asian descendent. 
Immunohistochemistry

Tissue microarrays (TMA) were constructed using two 1.0$\mathrm{mm}$ tissue cores from each cancer; $1.0-\mathrm{mm}$ cores of normal breast tissue were included as controls. TMAs were immunostained for the MT1 receptor and a series of biomarkers of interest using the antibodies, positive controls, and cut-offs for "positive" listed in Table 2. Negative controls were concurrently run, with the primary antibody replaced with buffer.

Five micron sections of the TMAs were stained with predetermined appropriate dilutions using the Dako Autostainer (Dako, Carpinteria, CA). MT1 receptor was determined with the melatonin receptor antibody in the kit by Bioscience Research Reagents (formerly Chemicon, Temecula, CA). In addition to the MT1 receptor, 18 biomarkers were evaluated in each tissue (Table 2). Antigen retrieval was performed in citrate buffer at $\mathrm{pH} 6.0$ under a pressure of 15 pounds per square inch for $3 \mathrm{~min}$. For CK8, citrate buffer was replaced by EDTA at pH 8.0. The EnVision + Dual Link Kit (Dako) which uses a polymer was the detection method used according to the manufacturer's instructions, with diaminobenzidine as the chromogen and hematoxylin as counterstain. For androgen receptor (AR), the $\mathrm{LSAB}_{2}$ DAKO detection kit was used.

All slides were examined by the same experienced breast pathologist who was blinded in regards to ethnic background and controls. The immunohistochemical expression of MT1 was semi-quantitatively graded as staining intensity $(0,1,2$, and 3 ) and as percentage of cells stained (0-100\%). The product of these two measurements resulted in a WI. In MT1 receptor staining, a WI of 60 or more was called positive, and
Table 1 Triple negative carcinomas of the breast (TNBC) in African American (AA) and Caucasian (C) women: number, ethnicity, and age of patients with TNBC

\begin{tabular}{|c|c|c|c|c|c|c|c|c|c|}
\hline \multirow[t]{3}{*}{ Ethnic group } & \multicolumn{3}{|c|}{ Below 50 years } & \multicolumn{3}{|c|}{ Above 50 years } & \multicolumn{3}{|c|}{ All Patients } \\
\hline & \multirow[t]{2}{*}{ No. } & \multicolumn{2}{|l|}{ Age } & \multirow[t]{2}{*}{ No. } & \multicolumn{2}{|l|}{ Age } & \multirow[t]{2}{*}{ No. } & \multicolumn{2}{|l|}{ Age } \\
\hline & & Mean & $\pm \mathrm{SD}$ & & Mean & $\pm \mathrm{SD}$ & & Mean & $\pm \mathrm{SD}$ \\
\hline African American & 35 & 38.7 & 6.6 & 46 & 61.2 & 8.9 & 81 & 51.4 & 13.7 \\
\hline Caucasian & 10 & 43.9 & 4.8 & 43 & 62.7 & 10.4 & 53 & 59.1 & 12.1 \\
\hline
\end{tabular}

Table 2 Antibodies used for immunohistological analysis

\begin{tabular}{|c|c|c|c|c|c|}
\hline Antibody & Clone & Dilution & Source & Positive control & $\begin{array}{l}\text { Cut-off } \\
\text { values }^{\text {a }}\end{array}$ \\
\hline Melatonin receptor MT1 & OPA1-15641 & $1: 40$ & Bioscience Research & Pineal & $\mathrm{WI}^{\mathrm{b}}>60$ \\
\hline CK5 or $5 / 6$ & D5/16B4 & $1: 80$ & DAKO & Mesothelioma & $5 \%$ \\
\hline CK7 & OB-TL 12/30 & $1: 40$ & DAKO & Non-small cell carcinoma of the lung & $5 \%$ \\
\hline CK8 & 35BH11 & $1: 40$ & DAKO & Pancreatic carcinoma & $5 \%$ \\
\hline CK14 & NCL-LL002 & $1: 40$ & Novocastra & Placenta & $5 \%$ \\
\hline CK18 & DC10 & $1: 10$ & DAKO & Carcinoid tumor & $5 \%$ \\
\hline CK19 & BA17 & $1: 50$ & DAKO & Colon carcinoma & $5 \%$ \\
\hline Vimentin & V9 & $1: 320$ & DAKO & Signet ring cell carcinoma & $5 \%$ \\
\hline CD44 & DF-1485 & $1: 2$ & Zymed & Prostate & $5 \%$ \\
\hline c-Kit (CD 117) & Polyclonal & $1: 800$ & DAKO & Gastrointestinal stromal tumor & $1 \%$ \\
\hline $\begin{array}{l}\text { Epidermal growth factor } \\
\text { receptor (EGFR) }\end{array}$ & FDA-Approved kit & Pre diluted & DAKO & Colon carcinoma & $1 \%$ \\
\hline $\begin{array}{l}\text { Insulin-like growth factor } \\
\text { receptor (IGFR) }\end{array}$ & Polyclonal & $1: 80$ & Santa Cruz Biotech & Prostate cancer & $\mathrm{WT}^{\mathrm{b}}>200$ \\
\hline P-cadherin (P-CADH) & $56 \mathrm{C} 1$ & $1: 40$ & Novocastra & Placenta & $10 \%$ \\
\hline p53 & D07 & $1: 80$ & DAKO & Colon carcinoma & $10 \%$ \\
\hline p63 & $4 \mathrm{~A} 4$ & $1: 160$ & Neomarkers & Squamous cell carcinoma of skin & $1 \%$ \\
\hline Topoisomerase (TOPO) & $\mathrm{Ki}-\mathrm{S} 1$ & $1: 160$ & DAKO & Melanoma of the skin & $5 \%$ \\
\hline Androgen receptor (AR) & F39.4.1 & $1: 40$ & DAKO & Breast carcinoma & $5 \%$ \\
\hline $\mathrm{Ki}-67$ & Mib-1 & $1: 160$ & DAKO & Tonsil & $10 \%$ \\
\hline Survivin (SVNC) & 3F343 (SC-73083) & $1: 60$ & Santa Cruz Biotech & Lymph node & $10 \%$ \\
\hline ZEB & E20 (SC-10572) & $1: 100$ & Santa Cruz Biotech & Breast cancer & $10 \%$ \\
\hline
\end{tabular}

${ }^{a}$ Percentage of cells with antibody staining

b Weighted index (WI): Intensity of staining $\times$ Percentage of positive cells 
any WI below this cut-off was negative (Fig. 1). The concordance of two separate cores for MT1 was assessed in 91 patients, and for each core the expression of MT1 was categorized as positive and negative. Kappa statistics were used with $\kappa=0.54(p<0.001)$.

Suitable cut-off values, based upon percentage of cells staining, and WIs were determined individually for each of the other markers as listed in Table 2. Carcinomas were considered positive if the percentage of cells with antibody staining was greater than or equal to the cut-off value of the respective marker. Percentages $(0-100 \%)$ were averaged between the two cores. Antigen expression is cytoplasmic for MT1, cytokeratins, vimentin, and CD44; membranous for c-Kit, EGFR, and P-cadherin; and nuclear for p53, p63, topoisomerase (TOPT), AR, Ki-67, and survivin.

\section{Statistical methods}

The optimal cut point for MT1 was determined by the maximum log rank test statistic method [47] based on MT1 WI. For univariate association with MT1 (negative vs. positive), numerical covariates were analyzed by ANOVA/ Wilcox sum rank test and Chi-Square/Fisher' exact test for categorical covariates. Multivariable logistic regression model was conducted to predict MT1 negative by backward elimination, in which a start up variable list contains all significant variables in the univariate association.

Progression free survival (PFS) and overall survival (OS) were associated with each clinical characteristic and immunohistochemical (IHC) MT1 expression individually and followed by a multivariable analysis through the Cox proportional hazards model by backward elimination, in which a start up variable list contains all significant variables in the univariate survival analysis. The OS is defined as days from date of diagnosis to either date of death, if the patient died, or to date of the last follow-up, if the patient is still alive. The PFS is defined as days from the date of diagnosis to the date of the first local recurrence or the first metastasis, whichever is earlier, if the patient progresses, or to the date of the last follow-up if the patient does not progress.

The correlation between two biomarkers was performed using the Spearman correlation coefficient.

The analyses and summary tables were done using SAS 9.2. The significance level was set at 0.05 .

\section{Results}

MT1 receptor and clinical characterizations

Table 3 shows the univariate correlation of MT1 with clinical characteristics at time of diagnosis. In regards to age, younger women with TNBC more frequently lacked MT1 expression. The difference was striking between ethnicities. AA women were more frequently MT1 negative $(48.8 \%$ in AA vs. $11.8 \%$ in $\mathrm{C})$. We conducted a multivariable logistic regression analysis for predicting negative MT1 expression, the odds ratio (OR) for AA compared to $\mathrm{C}$ was $5.91(p=0.001)$ after taking tumor size into account, which indicates that the relationship of MT1 expression with race was independent of the size of the tumors. The WI in patients below and above 50 years of age, was significantly higher in the $\mathrm{C}$ as compared to AA women (Table 4). A family history of breast cancer was more frequently associated with negative MT1 expression.

MT1-positive TNBCs were associated with a lower stage and with smaller mean tumor size at time of diagnosis. Neoadjuvant chemotherapy prior to surgery, grade of

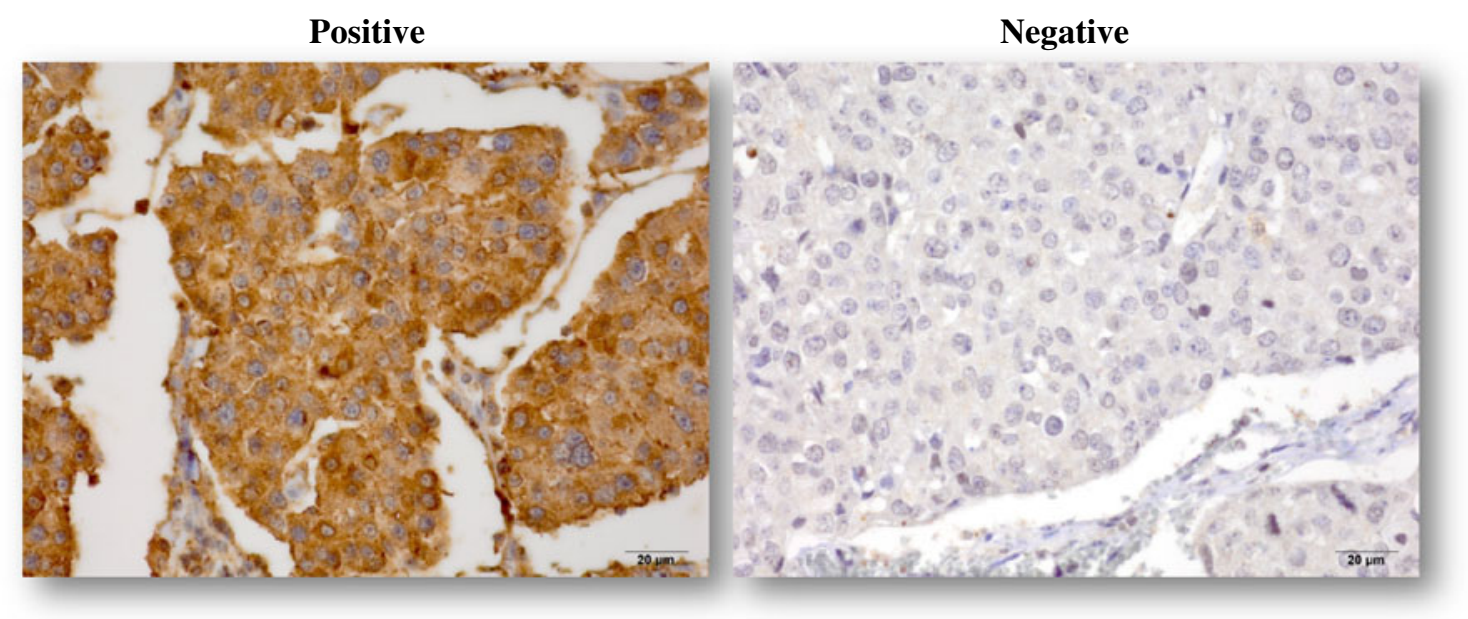

Fig. 1 TNBC immunostained with polyclonal MT1E for MT1 melatonin receptor $(40 \times)$. Left MT1 positive, right MT1 negative 
the tumor, lymphovascular invasion, and lymph node and distant metastases at the time of diagnosis in univariate analysis did not correlate with the MT1 expression.

\section{MT1 receptor expression and PFS and OS}

In multivariable survival analysis of TNBC in AA and C patients combined, tumors negative for MT1 showed significantly shorter PFS (hazard ratio, HR $=1.909$, $p=0.0343)$ and $\mathrm{OS}(\mathrm{HR}=2.015, p=0.0257)$, as did NPI, the Nottingham Prognositic Index [48], (PFS $\mathrm{HR}=1.434, p=0.0344 ;$ OS HR $=1.444, p=0.0259$ ) (Table 5). Stage I/II tumors showed a better PFS and OS compared to stage III/IV tumors (Table 5). Table 5 shows that MT1 is independent to NPI and Stage in terms of predicting survival. In other words, it indicates that after taking patient's disease characteristics (tumor size, LN, stage, grade as expressed by the Nottingham Prognostic Index) into account, MT1 makes an additional significant contribution to predict patient's survival. In considering the ethnic groups separately, the differences in survival advantage of MT1 positivity and increase in HR with absence of MT1 expression was statistically significant in the entire group of patients with AA and C combined. It was especially pronounced in the AA women, but did not reach statistical significance in the smaller number of $\mathrm{C}$ women alone (Table 6). In regards to age, MT1 positivity was statistically significantly related to improved PFS or OS in the women above 50 years of age but not in the smaller group of women below 50 years of age (Table 7). Figure 2 shows the Kaplan-Meier survival curves for PFS and $\mathrm{OS}$ in AA and $\mathrm{C}$ women combined with MT1 positive and MT1 negative TNBC. Figure 3 shows the comparable behavior in both subpopulations.

Correlation of MT1 WI and other biomarkers in TNBC in $\mathrm{AA}$ and $\mathrm{C}$ women

The absolute values of the biomarkers studied and their interracial differences were discussed in a series of publications from this laboratory [39, 49-51], and only their correlations with the MT1 receptor will be presented here.

The correlation between MT1 expression, WI, and the other biomarkers studied is shown in Table 8 separately and together for $\mathrm{AA}$ and $\mathrm{C}$ women and in Table 9 according to age.

The TNBC in the $\mathrm{C}$ women $(N=10-51$ women available for different biomarkers) showed a negative Spearman
Table 3 Univariate correlation of MT1 melatonin receptor in triple negative breast cancers with clinical characteristics at time of diagnosis

Statistically significant values are in bold

${ }^{a}$ The parametrical $\mathrm{p}$ value is calculated by ANOVA for numerical covariates and Chisquare test for categorical covariates

b The non-parametrical $p$ value is calculated by Wilcoxon statistics for numerical and Fisher's exact test for categorical covariates

\begin{tabular}{|c|c|c|c|c|c|}
\hline \multirow[t]{2}{*}{ Covariate } & \multirow[t]{2}{*}{ Level } & \multicolumn{2}{|l|}{ Number } & \multirow[t]{2}{*}{ Parametric $p$ value $^{\mathrm{a}}$} & \multirow{2}{*}{$\begin{array}{l}\text { Non-parametric } \\
p \text { value }^{\mathrm{b}}\end{array}$} \\
\hline & & Positive & Negative & & \\
\hline \multirow[t]{3}{*}{ Age } & $<40$ & 9 & 12 & \multirow[t]{3}{*}{0.046} & \multirow[t]{3}{*}{0.053} \\
\hline & $40-60$ & 50 & 24 & & \\
\hline & $>60$ & 33 & 12 & & \\
\hline \multirow[t]{2}{*}{ Race } & Caucasian & 45 & 6 & \multirow[t]{2}{*}{$<0.001$} & \multirow[t]{2}{*}{$<0.001$} \\
\hline & African American & 43 & 41 & & \\
\hline \multirow{2}{*}{$\begin{array}{l}\text { Family history of } \\
\text { breast cancer }\end{array}$} & No & 39 & 14 & \multirow[t]{2}{*}{$\mathbf{0 . 0 3 0}$} & \multirow[t]{2}{*}{0.044} \\
\hline & Yes & 19 & 18 & & \\
\hline \multirow[t]{2}{*}{ Stage } & I/II & 68 & 26 & \multirow[t]{2}{*}{0.017} & \multirow[t]{2}{*}{0.029} \\
\hline & III/IV & 21 & 20 & & \\
\hline \multirow[t]{3}{*}{ Tumor size } & Number & 92 & 48 & \multirow[t]{3}{*}{0.002} & \multirow[t]{3}{*}{0.027} \\
\hline & Mean & 2.42 & 3.92 & & \\
\hline & Median & 2.15 & 2.50 & & \\
\hline
\end{tabular}

Table 4 ANOVA summary MT1 receptor expression: ethnicity and age

\begin{tabular}{|c|c|c|c|c|c|c|c|}
\hline$F$ test & $p$ Value & Ethnic group & Age (years) & Number & Mean & $\mathrm{SE}$ & $p<0.05$ \\
\hline \multirow[t]{4}{*}{11.851} & \multirow[t]{4}{*}{0.0001} & African American & $<50$ & 35 & 69.06 & 12.26 & $<50:$ AA vs. $\mathrm{C}^{\mathrm{a}}$ \\
\hline & & \multirow[t]{3}{*}{ Caucasian } & $>50$ & 46 & 74.82 & 12.05 & \multirow[t]{3}{*}{$>50:$ AA vs. $\mathrm{C}^{\mathrm{b}}$} \\
\hline & & & $<50$ & 10 & 138.50 & 28.15 & \\
\hline & & & $>50$ & 43 & 170.60 & 16.27 & \\
\hline
\end{tabular}

MT1 receptor expression as weighted index (staining intensity $\times$ percentage of stained cancer cells). Ranges from 0 to 300

${ }^{\text {a }}$ By Fisher PLSD

b By Fisher PLSD and Scheffe $F$ test 
Table 5 Multivariate correlation of MT1 melatonin receptor in triple negative breast cancers with progress free survival (PFS) overall survival (OS) and with clinical characteristics at time of diagnosis

\begin{tabular}{|c|c|c|c|c|c|c|}
\hline \multirow[t]{2}{*}{ Variable } & \multirow[t]{2}{*}{ No. of subjects ${ }^{\mathrm{a}}$} & \multirow[t]{2}{*}{ Level } & \multicolumn{2}{|c|}{ Progress free survival (PFS) } & \multicolumn{2}{|c|}{ Overall survival (OS) } \\
\hline & & & Hazard ratio & $\mathrm{Pr}>\mathrm{Chi} \mathrm{Sq}$ & Hazard ratio & $\mathrm{Pr}>\mathrm{Chi} \mathrm{Sq}$ \\
\hline \multirow[t]{2}{*}{ MT1 receptor } & 44 & Negative & 1.909 & 0.0343 & 2.015 & 0.0257 \\
\hline & 89 & Positive (ref) & & & & \\
\hline $\mathrm{NPI}^{\mathrm{b}}$ & 133 & 1 Unit increase & 1.434 & 0.0344 & 1.444 & 0.0259 \\
\hline \multirow[t]{2}{*}{ Stage } & 94 & $\mathrm{I} / \mathrm{II}$ & 0.059 & $<0.0001$ & 0.138 & $<0.0001$ \\
\hline & 39 & III/IV (ref) & & & & \\
\hline
\end{tabular}

Statistically significant values are in bold

a The total number used in the multivariable analysis was 133 patients

b NPI (Nottingham Prognostic Index): $0.2 \times$ tumor size $(\mathrm{cm})+\mathrm{LN}(0=1,1-3=2,>3=3)+$ Grade

Table 6 Tumor progression free survival (PFS) and overall survival (OS) in African American and Caucasian American women with triple negative breast cancer (TNBC) negative or positive (score $\geq 60$ ) for MT1 melatonin receptor: survival analysis by race

\begin{tabular}{|c|c|c|c|c|}
\hline \multirow[t]{2}{*}{ Survival } & \multicolumn{4}{|c|}{ TNBC-MT1 receptor negative vs. positive } \\
\hline & Statistics & African American & Caucasian & Combined \\
\hline \multirow[t]{3}{*}{ Progression free survival } & Hazard ratio & 2.27 & 1.97 & 2.22 \\
\hline & $p$ Value & 0.022 & 0.311 & 0.006 \\
\hline & $\mathrm{N}$ & 84 & 51 & 137 \\
\hline \multirow[t]{2}{*}{ Overall survival } & blazahderatio & 0.062 & $0.0 \$ 6$ & 0.063 \\
\hline & $\mathrm{N}$ & 84 & 51 & 137 \\
\hline
\end{tabular}

Statistically significant values are in bold

Table 7 Tumor progression free survival (PFS) and overall survival (OS) in patients above and below 50 years of age with triple negative breast cancer $(\mathrm{TNBC})$ negative or positive $($ score $\geq 60$ ) for MT1 melatonin receptor: survival analysis by age

\begin{tabular}{lllll}
\hline Survival & \multicolumn{4}{l}{ TNBC-MT1 receptor negative vs. positive } \\
\cline { 2 - 5 } & Statistics & Age $<50$ & Age $>50$ & Combined \\
\hline Progression free & HR $^{\mathrm{a}}$ & 1.62 & 2.66 & 2.12 \\
survival (PFS) & $p$ Value & 0.269 & $\mathbf{0 . 0 1 1}$ & $\mathbf{0 . 0 0 9}$ \\
& $N$ & 54 & 86 & 140 \\
Overall survival & $\mathrm{HR}^{\mathrm{a}}$ & 2.02 & 2.95 & 2.42 \\
$(\mathrm{OS})$ & $p$ Value & 0.124 & $\mathbf{0 . 0 0 8}$ & $\mathbf{0 . 0 0 3}$ \\
& $N$ & 54 & 86 & 140
\end{tabular}

Statistically significant values are in bold

${ }^{\text {a }}$ Hazard ratio

correlation coefficient between the WI of melatonin and the expression of CK14 $(-0.307, p=0.032)$ and $\mathrm{p} 53(-0.422$, $p=0.003$ ) with no statistically significant correlation to any other biomarker (Table 8 ).

In the AA women $(N=64-84$ women available for different biomarkers), there was a positive correlation of the WI of MT1 with CD44 $(0.258, p=0.020)$, CK7 $(0.262$, $p=0.017)$, and $\operatorname{CK} 8(0.284, p=0.011)$ and a negative correlation with EGFR $(-0.219, \quad p=0.049)$, Ki-67 $(-0.332, p=0.002)$, and survivin $(-0.324, p=0.003)$.

When the biomarkers in the entire group of TNBC of both $\mathrm{AA}$ and $\mathrm{C}$ were examined together irrespective of age,
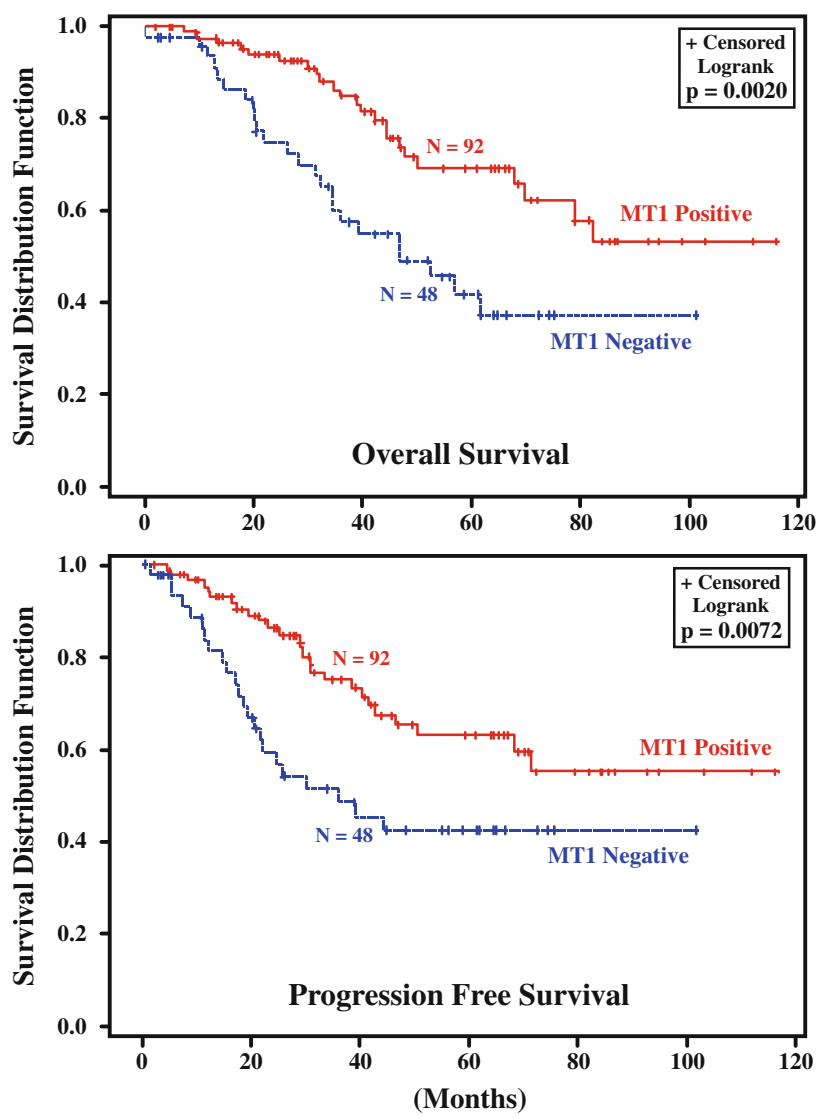

Fig. 2 Overall and progression free survival of patients with TNBC with and without MT1 melatonin receptors 
positive correlations of the WI of MT1 was found with the AR (0.191, $p=0.026)$, CD44 (0.303, $p<0.001)$, CK19 (0.310, $p<0.001)$, CK5 (0.330, $p<0.001)$, CK7 (0.279, $p=0.001)$, CK8 (0.367, $p=0.001)$, and IGFR (0.257, $p=0.006)$, and negative correlations were observed with Ki-67 (-0.326, $p<0.001)$, p53 (-0.296, $p<0.001)$, and survivin $(-0.256, p=0.011)$. For survivin, only 10 tumors were available in $\mathrm{C}$. The WI of CK5/6, c-Kit, p63, p-CADH, TOPO, UPARNC, Vimentin, and ZEB did not show any statistically significant correlation with MT1 receptors in AA or C-tumors.

The analysis based on this database could not confirm that the status of $\mathrm{Ki}-67$ and p53 can predict OS or PFS, and hence
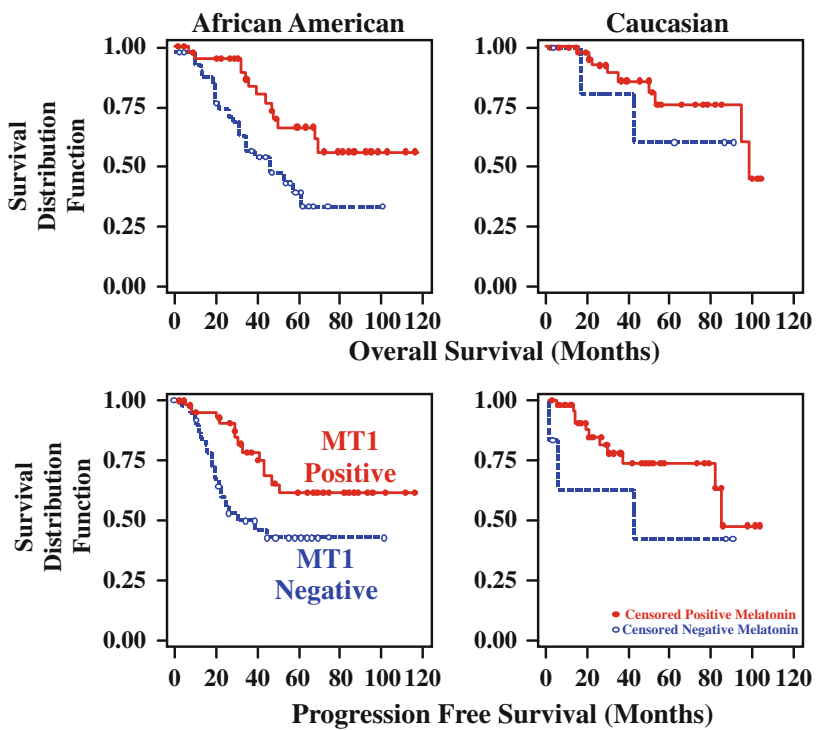

Fig. 3 Overall and progression free survival of African American and Caucasian Women with TNBC with and without MT1 melatonin receptors

Table 8 Correlation between MT1 expression (as weighted index [WI]) and biomarkers (WI) by race

\begin{tabular}{|c|c|c|c|c|c|c|c|c|}
\hline \multirow[t]{2}{*}{ Biomarker } & \multicolumn{3}{|c|}{ African American (AA) } & \multicolumn{3}{|c|}{ Caucasian (C) } & \multicolumn{2}{|c|}{$\mathrm{AA}+\mathrm{C}$ Combined } \\
\hline & Coefficient $^{\mathrm{a}}$ & $p$ Value & $N$ & Coefficient $^{\mathrm{a}}$ & $p$ Value & $N$ & Coefficient $^{\mathrm{a}}$ & $p$ Value \\
\hline $\begin{array}{l}\text { Androgen receptor } \\
\text { (AR) }\end{array}$ & 0.098 & 0.380 & 82 & 0.203 & 0.158 & 50 & 0.191 & 0.026 \\
\hline CD44 & 0.258 & 0.020 & 81 & 0.172 & 0.228 & 51 & 0.303 & $<0.001$ \\
\hline CK14 & 0.030 & 0.792 & 82 & -0.307 & 0.032 & 49 & -0.058 & 0.503 \\
\hline CK18 & 0.025 & 0.825 & 81 & -0.907 & 0.506 & 49 & 0.194 & 0.024 \\
\hline CK19 & 0.171 & 0.122 & 83 & 0.059 & 0.687 & 49 & 0.310 & $<0.001$ \\
\hline CK5 & -0.172 & 0.119 & 84 & 0.102 & 0.481 & 50 & 0.330 & $<0.001$ \\
\hline CK7 & 0.262 & 0.017 & 82 & 0.003 & 0.982 & 50 & 0.279 & 0.001 \\
\hline CK8 & 0.284 & 0.011 & 80 & 0.111 & 0.441 & 50 & 0.367 & $<0.001$ \\
\hline EGFR & -0.219 & 0.049 & 82 & -0.065 & 0.656 & 50 & -0.069 & 0.425 \\
\hline IGFR & 0.000 & 0.997 & 64 & 0.137 & 0.374 & 44 & 0.257 & 0.006 \\
\hline Ki67 & -0.332 & 0.002 & 83 & -0.150 & 0.298 & 50 & -0.326 & $<0.001$ \\
\hline p53 & -0.197 & 0.076 & 82 & -0.422 & 0.003 & 49 & -0.296 & $<0.001$ \\
\hline SVNC & -0.324 & 0.003 & 82 & 0.472 & 0.168 & 10 & -0.256 & 0.011 \\
\hline
\end{tabular}

was not able to assess the independence of MT1 relative to those two biomarkers in terms of survival. However, based on the multivariate analysis (Table 5), we can conclude that MT1 was independent of stage and NPI (Nottingham Prognostic Index: $0.2 \times$ tumor size $(\mathrm{cm})+\mathrm{LN}+$ Grade).

Compared according to age $\mathrm{AA}$ and $\mathrm{C}$ patients combined (Table 9) showed in the TNBC of women below 50 years of age, a positive correlation between the WI of MT1 and the expression of CD44, CK19, CK8, and IGFR, and a negative correlation with $\mathrm{p} 53$ and survivin. In women above 50 years of age, there were statistically significant positive correlations between MT1 and AR, CD44, CK19, CK5, CK7, and $\mathrm{C} 8$, and negative correlations with $\mathrm{Ki}-67$ and p53. In both age groups combined, a positive correlation was found in AR, CD44, CK18, CK19, CK5, CK7, CK8, IGFR, and a negative correlation in $\mathrm{Ki}-67, \mathrm{p} 53$, and survivin.

\section{Discussion}

MT1 receptors were present in a percentage of TNBC with marked differences in expression between $\mathrm{AA}$ and $\mathrm{C}$ women. The frequency and staining intensity of MT1 expression was significantly higher in the tumors in $\mathrm{C}$ as compared to AA women. This difference between the TNBC in C and in AA women is of interest in view of their different biologic behaviors [37, 39, 52]. In regards to the course of the disease, patients with absent or low MT1 expression showed a worse prognosis with shorter DFS and OS ' than patients with MT1-positive tumors. This was manifest in the population as a whole with AA and $\mathrm{C}$ combined, and was statistically significant in the AA TNBC, but did not quite reach statistical significance in the smaller group of $\mathrm{C}$ alone, though these patients did exhibit
Statistically significant values are in bold

a Spearman Correlation Coefficient 
Table 9 Correlation between MT1 expression (as weighted index $[\mathrm{WI}]$ ) and biomarkers (WI) by age

\begin{tabular}{|c|c|c|c|c|c|c|c|c|}
\hline \multirow[t]{2}{*}{ Biomarker } & \multicolumn{3}{|c|}{$<50$ years of age } & \multicolumn{3}{|c|}{$>50$ years of age } & \multicolumn{2}{|l|}{ All ages } \\
\hline & Coefficient $^{\mathrm{a}}$ & $p$ Value & $N$ & Coefficient $^{\mathrm{a}}$ & $p$ Value & $N$ & Coefficient $^{\mathrm{a}}$ & $p$ Value \\
\hline $\begin{array}{l}\text { Androgen } \\
\text { receptor (AR) }\end{array}$ & 0.010 & 0.943 & 51 & 0.273 & 0.012 & 85 & 0.191 & 0.026 \\
\hline CD44 & 0.355 & 0.010 & 52 & 0.269 & 0.013 & 85 & 0.303 & $<0.001$ \\
\hline CK14 & -0.110 & 0.432 & 53 & -0.005 & 0.966 & 83 & -0.058 & 0.503 \\
\hline CK18 & 0.181 & 0.200 & 52 & 0.150 & 0.180 & 82 & 0.194 & 0.024 \\
\hline CK19 & 0.355 & 0.010 & 52 & 0.259 & 0.018 & 84 & 0.310 & $<0.001$ \\
\hline CK5 & 0.133 & 0.338 & 54 & 0.436 & $<0.001$ & 84 & 0.330 & $<0.001$ \\
\hline CK7 & 0.217 & 0.119 & 53 & 0.280 & 0.010 & 84 & 0.279 & 0.001 \\
\hline CK8 & 0.296 & 0.032 & 53 & 0.375 & 0.001 & 81 & 0.367 & $<0.001$ \\
\hline EGFR & -0.104 & 0.461 & 52 & -0.033 & 0.768 & 84 & -0.069 & 0.425 \\
\hline IGFR & 0.313 & 0.041 & 43 & 0.216 & 0.075 & 69 & 0.257 & 0.006 \\
\hline Ki67 & -0.233 & 0.091 & 54 & -0.383 & $<0.001$ & 84 & -0.326 & $<0.001$ \\
\hline p53 & -0.306 & 0.026 & 53 & -0.280 & 0.011 & 82 & -0.296 & $<0.001$ \\
\hline SVNC & -0.358 & 0.020 & 42 & -0.214 & 0.116 & 55 & -0.256 & 0.011 \\
\hline
\end{tabular}

a higher positivity rate and stronger expression of MT1 and a more favorable prognosis than the AA group. MT1 expression was associated with other prognostically favorable features like smaller tumor size and lower grade at the time of diagnosis, which appears to be associated with less aggressive TNBC with more favorable outcome. MT1 was negatively correlated with the proliferation marker Ki-67 which is associated with an unfavorable outcome in other forms of breast cancer [53, 54], and in the AA only with EGFR, which is also associated with an unfavorable outcome in TNBC $[38,55]$. In this context, the possibility of a loss of MT1 expression through clonal evolution in the larger and more aggressive tumors may have to be considered. MT1 expression was uniform at different sites of the same tumor as expressed by the high degree of concordance.

There appears to be a difference in pineal function and circulating melatonin concentrations and the development of breast cancer. Melatonin levels in first morning urine were reported to show an inverse correlation with breast cancer risk [56]. Conditions which favor melatonin suppression by light during the night, including shiftwork, have been reported to represent risk factors for the development of breast cancer [56-60]. In human subjects, with suppression of melatonin, e.g., by light during the night as experienced by shiftworkers exposed over a prolonged time span to nightwork, an increase of breast cancer incidence has been reported [60]. A most recent report found this increase to occur predominantly in TNBC [61].

A strong inverse correlation was observed between circulating plasma melatonin concentration and the amounts of ER and PR in the primary tumor [62]. There is a relation between the circadian rhythms in plasma melatonin and the steroid receptor content of the primary breast cancer.
Women with ER or PR positive tumors show a significantly lower mean plasma melatonin day-night difference than did patients with ER or PR negative tumors [62].

Melatonin acts over several signaling pathways that control normal breast epithelium and breast cancer [6, 6366]. The anti-proliferative effects of the circadian melatonin signal are in general, but not exclusively, mediated by activation of MT1.

In ER-positive human breast cancer cells, melatonin suppresses ER $\alpha$ mRNA expression and estrogen-induced transcriptional activity [23]. Melatonin regulates the transcriptional activity of other members of the nuclear receptor super family of enzymes involved in peripheral estrogen metabolism. Beyond that melatonin blocks the uptake of linoleic acid and its transformation in 13-hydroxyoctadecadienoic acid (HODE), a mitogenic compound [64]. Melatonin also exerts anti-invasive and antimetastatic effects through blockade of 38 phosphorylation and matrix metalloprotein expression [6, 63].

Overexpression of the MT1 receptor in transfected MCF-7 human breast cancer cells induced inhibition of aromatase mRNA expression [24] and inhibited human MCF-7 cell proliferation-derived mammary tumor formation in male mice [67, 68]. Melatonin agonists exhibit enhanced antitumor potency in experimental models [23]. Additional new melatonin agonists with a variation of properties are being developed in research laboratories and by industry $[5,69,70]$. The anti-proliferative effect of MT1 receptor overexpression was blocked by a MT1/MT2 receptor antagonist (S20928 Servier) [67].

Manipulation of MT1 receptors by the anti-epileptic valproic acid has been reported and may be of interest for enhancement of melatonin effects upon cell proliferation. Clinically relevant concentrations of valproic acid 
upregulate melatonin MT1 receptor expression in human breast cancer cells (MCF-7B) [71]. There was an enhanced anti-proliferation effect on these cells through a combination of valproic acid and melatonin [71]. Tumor cell growth inhibition in vitro and in vivo by valproic acid and other anti-epileptic agents has been reported in animal experiments [72-76]. The anti-proliferation effect of antiepileptic drugs may be related to their MT1 up-regulation.

Although the association of the MT1 expression with a more favorable course of TNBC is not direct evidence for melatonin effects on this tumor, the extensive experimentation on the mechanistic aspects of apparent melatonin effects makes a causal relation appear likely.

Randomized controlled trials of melatonin treatment, including breast cancer, have been evaluated in two metaanalyses of published reports $[77,78]$. It was concluded that melatonin as an adjuvant therapy to cancer may lead to improvement in tumor remission and survival and may ameliorate the side-effects of chemotherapy or radiotherapy. Our findings of the apparently favorable aspects of MT1 receptor expression in patients with TNBC support these findings and suggest the possible utility of melatonin or of longer acting melatonin agonists [23] in TNBC, a type of tumor for which no other targeted treatment is available at this time. This effect may be linked to the presence of MT1 receptors in the tumor but also other mechanisms like immune stimulation by melatonin [79] have to be considered. More research in this direction is needed.

Acknowledgments We thank Dr. Brent Clark, Professor of Neuropathology, University of $\mathrm{MN}$, for generously providing pineal tissue for positive control for MT1. This study was supported by the HealthPartners Institute for Education and Research and the Department of Pathology, Regions Hospital, St. Paul, MN. The support of Ms Violetta Krstich in the preparation of the manuscript is acknowledged.

Conflict of interest Authors have no financial relationship with the sponsoring agencies. The authors decree that they have no conflict of interest.

Ethical standards The Study was approved by the IRB at Emory University and complies with the current laws of the USA and by the Research Oversight Committee (ROC) at Grady Memorial Hospital.

Open Access This article is distributed under the terms of the Creative Commons Attribution Noncommercial License which permits any noncommercial use, distribution, and reproduction in any medium, provided the original author(s) and the source are credited.

\section{References}

1. Reiter RJ (1991) Pineal melatonin: cell biology of its synthesis and of its physiological interactions. Endocr Rev 12:151-180. doi:10.1210/edrv-12-2-151

2. Reiter RJ (1993) The melatonin rhythms: both a clock and a calendar. Experientia 49:654-664
3. Reiter RJ, Tan DX, Jou MJ, Korkmaz A, Manchester LC, Paredes SD (2008) Biogenic amines in the reduction of oxidative stress: melatonin and its metabolites (Review). Neuro Endocrinol Lett 29:391-398

4. Dubocovich ML, Markowska M (2005) Functional MT1 and MT2 melatonin receptors in mammals. Endocrine 27:101-110. doi:10.1385/ENDO:27:2:101

5. Dubocovich ML, Delagrange P, Krause DN, Sugden D, Cardinali DP, Olcese J (2010) International union of basic and clinical pharmacology. LXXV. Nomenclature, classification, and pharmacology of $\mathrm{G}$ protein-coupled melatonin receptors. Pharmacol Rev 62:343-380. doi:10.1124/pr.110.002832

6. Hill SM, Frasch T, Xiang S, Yuan L, Duplessis T, Mao L (2009) Molecular mechanisms of melatonin anticancer effects. Integr Cancer Ther 8:337-346

7. Blask DE, Sauer LA, Dauchy RT (2002) Melatonin as a chronobiotic anti-cancer agent: cellular, biochemical, and molecular mechanisms of action and their implications for circadian-based cancer therapy (Review). Curr Top Med Chem 2:113-132

8. Hill SM, Blask DE (1988) Effects of the pineal hormone melatonin on the proliferation and morphological characteristics of human breast cancer cells (MCF-7) in culture. Cancer Res 48: $6121-6126$

9. Blask DE, Brainard GC, Dauchy RT, Hanifin JP, Davidson LK, Kranse JA, Sauer LA, Rivera-Bermudez MA, Dubocovich ML, Jasser SA, Lynch DT, Rollag MD, Zallatan F (2005) Melatonin depleted blood from premenopausal women exposed to light at night stimulates growth of human breast cancer xenografts in nude rats. Cancer Res 65:11174-11184. doi:10.1158/0008-5472. CAN-05-1945

10. Dauchy RT, Dauchy EM, Sauer LA, Blask DE, Davidson LK, Krause JA, Lynch DT (2004) Differential inhibition of fatty acid transport in tissue-isolated steroid receptor negative human breast cancer xenografts perfused in situ with isomers of conjugated linoleic acid. Cancer Lett 209:7-15. doi:10.1016/j.canlet.2003. 12.012

11. Xi SC, Siu SW, Fong SW, Shiu SY (2001) Inhibition of androgensensitive LNCaP prostate cancer growth in vivo by melatonin: association of antiproliferative action of the pineal hormone with $\mathrm{mt} 1$ receptor protein expression. Prostate 46:52-61. doi:10.1002/ 1097-0045(200101)46:1<52:AID-PROS1008>3.0.CO;2-Z

12. Sainz RM, Mayo JC, Tan DX, León J, Manchester L, Reiter RJ (2005) Melatonin reduces prostate cancer cell growth leading to neuroendocrine differentiation via a receptor and PKA independent mechanism. Prostate 63:29-43. doi:10.1002/pros.20155

13. Karasek M, Carrillo-Vico A, Guerrero JM, Winczyk K, Pawlikowski M (2002) Expression of melatonin MT(1) and MT(2) receptors, and ROR alpha(1) receptor in transplantable murine Colon 38 cancer. Neuro Endocrinol Lett 23:55-60

14. Bartsch H, Buchberger A, Franz H, Bartsch C, Maidonis I, Mecke D, Bayer E (2000) Effect of melatonin and pineal extracts on human ovarian and mammary tumor cells in a chemosensitivity assay. Life Sci 67:2953-2960. doi:10.1016/S0024-3205(00) 00882-1

15. Kobayashi Y, Itoh MT, Kondo H, Okuma Y, Sato S, Kanishi Y, Hamada N, Kiguchi K, Ishizuka B (2003) Melatonin binding sites in estrogen receptor-positive cells derived from human endometrial cancer. J Pineal Res 35:71-74. doi:10.1046/j.1439-0434. 2002.00691_2.x-i1

16. Blask DE, Dauchy RT, Sauer LA, Krause JA (2004) Melatonin uptake and growth prevention in rat hepatoma 7288CTC in response to dietary melatonin: melatonin receptor-mediated inhibition of tumor linoleic acid metabolism to the growth signaling molecule 13-hydroxyoctadecadienoic acid and the potential role of phytomelatonin. Carcinogenesis 25:951-960. doi:10.1093/carcin/ bgh090 
17. Leja-Szpak A, Jaworek J, Pierzchalski P, Reiter RJ (2010) Melatonin induces pro-apoptotic signaling pathway in human pancreatic carcinoma cells (PANC-1). J Pineal Res 49:248-255. doi: 10.1111/j.1600-079X.2010.00789.x

18. Ying SW, Niles LP, Crocker C (1993) Human malignant melanoma cells express high-affinity receptors for melatonin: antiproliferative effects of melatonin and 6-chloromelatonin. Eur J Pharmacol 246:89-96

19. Kadekaro AL, Andrade LN, Floeter-Winter LM, Rollag MD, Virador V, Vieira W, Castrucci AM (2004) MT-1 melatonin receptor expression increases the antiproliferative effect of melatonin on S-91 murine melanoma cells. J Pineal Res 36:204-211. doi:10.1111/j.1600-079X.2004-00119.x

20. Fischer TW, Zmijewski MA, Zbytek B, Sweatman TW, Slominski RM, Wortsman J, Slominski A (2006) Oncostatic effects of the indole melatonin and expression of its cytosolic and nuclear receptors in cultured human melanoma cell lines. Int $\mathrm{J}$ Oncol 29:665-672

21. Nakamura E, Kozaki K, Tsuda H, Suzuki E, Pimkhaokham A, Yamamoto G, Irie T, Tachikawa T, Amagasa T, Inazawa J, Imoto I (2008) Frequent silencing of a putative tumor suppressor gene melatonin receptor 1 A (MTNR1A) in oral squamous-cell carcinoma. Cancer Sci 99:1390-1400. doi:10-1111/j.1349-7006. 2008.00838.x

22. Martín V, Herrera F, Carrera-Gonzalez P, García-Santos G, Antolín I, Rodriguez-Blanco J, Rodriguez C (2006) Intracellular signaling pathways involved in the cell growth inhibition of glioma cells by melatonin. Cancer Res 66:1081-1088. doi:10.1158/ 0008-5472.CAN-05-2354

23. Mao L, Cheng Q, Guardiola-Lemaître B, Schuster-Klein C, Dong C, Lai L, Hill SM (2010) In vitro and in vivo antitumor activity of melatonin receptor agonists. J Pineal Res 49:210-221. doi: 10.1111/j.1600-079X.2010.00781.x

24. González A, Martínez-Campa C, Mediavilla MD, AlonsoGonzález C, Sánchez-Mateos S, Hill SM, Sánchez-Barceló EJ, Cos S (2007) Effects of MT1 melatonin receptor overexpression on the aromatase-suppressive effect of melatonin in MCF-7 human breast cancer cells. Oncol Rep 17:947-953

25. Cos S, Sanchez-Barcelo E (1995) Melatonin inhibition of MCF-7 human breast cancer cells growth: influence of cell proliferation rate. Cancer Lett 93:207-212. doi:10.1016/0304-3835(96) 03811-A

26. Lai L, Yuan L, Cheng Q, Dong C, Mao L, Hill SM (2009) Alteration of the MT1 melatonin receptor gene and its expression in primary human breast tumors and breast cancer cell lines. Breast Cancer Res Treat 118:293-305. doi:10.1007/s10549-0080220-1

27. Blask DE, Hill SM, Orstead KM, Massa JS (1986) Inhibitory effects of the pineal hormone melatonin and underfeeding during the promotional phase of 7,12-dimethylbenzanthracene-(DMBA)induced mammary tumorigenesis. J Neural Transm 67:125-138

28. Blask DE, Sauer LA, Dauchy RT, Holowachuk EW, Ruhoff MS (1999) New insights into melatonin regulation of cancer growth. Adv Exp Med Biol 460:337-343

29. Subramanian A, Kothari L (1991) Melatonin, a suppressor of spontaneous murine mammary tumors. J Pineal Res 10:136-140

30. Sanchez-Barcelo EJ, Mediavilla MD, Tucker HA (1990) Influence of melatonin on mammary gland growth: in vivo and in vitro studies. Proc Soc Exp Biol Med 194:103-107

31. Ram PT, Dai J, Yuan L, Dong C, Kiefer TL, Lai L, Hill SM (2002) Involvement of the MT1 melatonin receptor in human breast cancer. Cancer Lett 179:141-150

32. Kiefer T, Ram PT, Yuan L, Hill SM (2002) Melatonin inhibits estrogen receptor transactivation and cAMP levels in breast cancer cells. Breast Cancer Res Treat 71:37-45. doi:10.1023/A: 1013301408464
33. Brydon L, Roka F, Petit L, de Coppet P, Tissot M, Barrett P, Morgan PJ, Nanoff C, Strosberg AD, Jockers R (1999) Dual signaling of human Mel1a melatonin receptors via G(i2), G(i3) and G(q/11) proteins. Mol Endocrinol 13:2025-2038. doi:10.12 10/me.13.12.2005

34. Dillon DC, Easley SE, Asch BB, Cheney RT, Brydon L, Jockers R, Winston JS, Brooks JS, Hurd T, Asch HL (2002) Differential expression of high-affinity melatonin receptors (MT1) in normal and malignant breast tissue. Am J Clin Pathol 118:451-458

35. Sorlie T, Tibshirani R, Parker J, Hastie T, Marron JS, Nobel A, Deng S, Johnsen H, Pesich R, Geisler S, Demeter J, Perou CM, Lønning PE, Brown PO, Børresen-Dale AL, Botstein D (2003) Repeated observation of breast tumor subtypes in independent gene expression data sets. PNAS 100:8418-8423. doi:10.1073/ pnas.0932692100

36. Fadare O, Tavassoli FA (2007) The phenotypic spectrum of basal-like breast cancers: a critical appraisal (Review). Adv Anat Pathol 14:358-373. doi:10.1097/PAP.06013e31814b26fe

37. Foulkes WD, Smith IE, Reis-Filho JS (2010) Triple-negative breast cancer. N Engl J Med 363:1938-1948

38. Cheang MC, Voduc D, Bajdik C, Leung S, McKinney S, Chia SK, Perou CM, Nielsen TO (2008) Basal-like breast cancer defined by five biomarkers has superior prognostic value than triple-negative phenotype. Clin Cancer Res 14:1368-1376. doi: 10.1158/1078-0432.CCR-07-1658

39. Lund MJ, Trivers KF, Porter PL, Coates RJ, Leyland-Jones B, Brawley OW, Flagg EW, O’Regan RM, Gabram SG, Eley JW (2009) Race and triple negative threats to breast cancer survival: a population-based study in Atlanta, GA. Breast Cancer Res Treat 113:357-370. doi:10.1007/s10549-008-9926-3

40. Lara-Medina F, Pérez-Sánchez V, Saavedra-Pérez D, BlakeCerda M, Arce C, Motola-Kuba D, Villarreal-Garza C, GonzálezAngulo AM, Bargalló E, Aguilar JL, Mohar A, Arrieta Ó (2011) Triple-negative breast cancer in Hispanic patients: high prevalence, poor prognosis, and association with menopausal status, body mass index, and parity. Cancer 117:3658-3669. doi:10.10 02/cncr.25961

41. Korkmaz A, Reiter RJ, Topal T, Manchester LC, Oter S, Tan DX (2009) Melatonin an established antioxidant worthy of use in clinical trials. Mol Med 15:43-50. doi:10.2119/molmed.2008. 00117

42. Lissoni P, Meregalli S, Nosetto L, Barni S, Tancini G, Fossati V, Maestroni GJ (1996) Increased survival time in brain glioblastomas by a radioneuroendocrine strategy with radiotherapy plus melatonin compared to radiotherapy alone. Oncology 53:43-46

43. Lissoni $\mathrm{P}$, Barni $\mathrm{S}$, Mandalà M, Avdizzoia A, Paolorossi F, Vaghi M, Longarini R, Malugani F, Tancini G (1999) Decreased toxicity and increased efficacy of cancer chemotherapy using the pineal hormone melatonin in metastatic solid tumor patients with poor clinical status. Eur J Cancer 35:1688-1692. doi:10.1016/ S0959-8049(99)00159-8

44. Lissoni P, Rovelli F, Malugani F, Bucovec R, Conti A, Maestroni GJ (2001) Anti-angiogenic activity of melatonin in advanced cancer patients. Neuro Endocrinol Lett 22:45-47

45. Panzer A, Viljoen M (1997) The validity of melatonin as an oncostatic agent. J Pineal Res 22:184-202

46. Hrushesky WJM (2001) Melatonin in cancer therapy. In: Bartsch C, Bartsch H, Blask DE, Cardinali DP, Hrushesky WJM, Mecke D (eds) The pineal gland and cancer. Spring, Berlin, pp 476-508

47. Contal C, O'Quigley J (1999) An application of changepoint methods in studying the effect of age on survival in breast cancer. Comp Stat Data Anal 30:253-270. doi:10.1016/S0167-9473(98) 00096-6

48. Haybittle JL, Blamey RW, Elston CW, Johnson J, Doyle PJ, Campbell FC, Nicholson RI, Griffiths K (1982) A prognostic index in primary breast cancer. Br J Cancer 45:361-366 
49. Lund MJ, Butler EN, Bumpers HL, Okoli J, Rizzo M, Hatchett N, Green VL, Brawley OW, Oprea-Ilies GM, Gabram SG (2008) High prevalence of triple-negative tumors in an urban cancer center. Cancer 113:608-615. doi:10.1002/cncr.23569

50. Lund MJ, Butler EN, Hair BY, Ward KC, Andrews JH, OpreaIlies G, Bayakly AR, O'Regan RM, Vertino PM, Eley JW (2010) Age/race differences in Her2 testing and in incidence rates for breast cancer triple subtypes: a population-based study and first report. Cancer 116:2549-2559. doi:10.1002/cncr.25016

51. Sullivan HC, Oprea G, Adams A, Page AJ, Cohen C (2012) Triple negative breast carcinoma in African American and Caucasian women: clinicopathology, immunomarkers, and outcome. Appl Immunohistochem Mol Morphol (in print)

52. Carey LA, Perou CM, Livasy CA, Dressler LG, Cowan D, Conway K, Karaca G, Troester MA, Tse CK, Edmiston S, Deming SL, Geradts J, Cheang MC, Nielsen TO, Moorman PG, Earp HS, Millikan RC (2006) Race, breast cancer subtypes, and survival in the Carolina Breast Cancer Study. JAMA 295: 2492-2502. doi:10.1001/jama.295.21.2492

53. Williams JD, Cohen C, Darrow M, Page AJ, Chastain B, Adams AL (2011) Proliferation (Ki-67 and phosphohistone H3) and oncotype Dx recurrence score in estrogen receptor-positive breast cancer. Appl Immunohistochem Mol Morphol 19:431-436. doi: 10.1097/PAI.0b013e318206d23d

54. Allison KH, Kandalaft PL, Sitlani CM, Dintzis SM, Gown AM (2012) Routine pathologic parameters can predict oncotype Dx recurrence scores in subsets of ER positive patients who does not always need testing. Breast Cancer Res Treat 131:413-424. doi: 10.1007/s10549-011-1416-3

55. Tischkowitz M, Brunet J-S, Bégin LR, Huntsman DG, Cheang MC, Akslen LA, Nielsen TO, Foulkes WD (2007) Use of immunohistochemical markers can refine prognosis in triple negative breast cancer. BMC Cancer 7:134. doi:10.1186/14712407-7-134

56. Schernhammer ES, Hankinson SE (2005) Urinary melatonin levels and breast cancer risk. J Natl Cancer Inst 97:1084-1087. doi:10.1093/jnci/dji190

57. Stevens RG (1987) Electric power use and breast cancer: a hypothesis (Review and Commentary). Am J Epidemiol 125: 556-561

58. Stevens RG (2009) Light-at-night, circadian disruption and breast cancer: assessment of existing evidence. Int J Epidemiol 38 : 963-970. doi:10.1093/ije/dyp178

59. Costa G, Haus E, Stevens R (2010) Shift work and cancerconsiderations on rationale, mechanisms, and epidemiology. Scand J Work Environ Health 36:163-179. doi:10.5271/sjweh. 2899

60. International Agency for Research in Cancer (IARC) (2010) Monographs on the evaluation of carcinogenic risks to humans, vol 98: painting, firefighting and shiftwork. IARC, Lyon

61. Harth V, Bruning T, Rabstein S, Spickenheuser A, Bonberg N, Pesch B, Pallapies D (2011) Night-work and estrogen receptor status. In: Proceedings of the 20th international symposium on shiftwork and working time, Stockholm, Sweden, 28 June-1 July 2011

62. Danforth DN Jr, Tamarkin L, Mulvihill JJ, Bagley CS, Lippman ME (1985) Plasma melatonin and the hormone-dependency of human breast cancer. J Clin Oncol 3:941-948

63. Hill SM, Blask DE, Xiang S, Yuan L, Mao L, Dauchy RT, Dauchy EM, Frasch T, Duplesis T (2011) Melatonin and associated signaling pathways that control normal breast epithelium and breast cancer (Review). J Mammary Gland Biol Neoplasia 16:235-245. doi:10.1007/S10911-011-9222-4

64. Blask DE, Hill SM, Dauchy RT, Xiang S, Yuan L, Duplessis T, Mao L, Dauchy E, Sauer LA (2011) Circadian regulation of molecular, dietary, and metabolic signaling mechanisms of human breast cancer growth by the nocturnal melatonin signal and the consequences of its disruption by light at night. J Pineal Res 51:259-269. doi:10.1111/j.1600-079X.2011.00888.x

65. Mediavilla MD, Sanchez-Barcelo EJ, Tan DX, Manchester L, Reiter RJ (2010) Basic mechanisms involved in the anti-cancer effects of melatonin. Curr Med Chem 17:4462-4481

66. Girgert R, Hanf V, Emons G, Gründker C (2009) Membranebound melatonin receptor MT1 down-regulates estrogen responsive genes in breast cancer cells. J Pineal Res 47:23-31. doi: 10.1111/j.1600-079X.2009.00684.X

67. Yuan L, Collins AR, Dai J, Dubocovich ML, Hill SM (2002) MT(1) melatonin receptor overexpression enhances the growth suppressive effect of melatonin in human breast cancer cells. Mol Cell Endocrinol 192:147-156. doi:10.1016/S0303-7207(02) 00029-1

68. Collins A, Yuan L, Kiefer TL, Cheng Q, Lai L, Hill SM (2003) Over-expression of the MT1 melatonin receptor in MCF-7 human breast cancer cells inhibits mammary tumor formation in nude mice. Cancer Lett 189:49-57

69. Rivara S, Mor M, Bedini A, Spadoni G, Tavzia G (2008) Melatonin receptor agonists: SAR and applications to the treatment of sleep-wake disorders (Review). Curr Top Med Chem 8:954-968

70. Rajaratnam SMW, Polymeropoulos MH, Fisher DM, Roth T, Scott C, Birznieks G, Klerman EB (2009) Melatonin agonist tasimelteon (VEC-162) for transient insomnia after sleep-time shift: two randomized controlled multicenter trials. Lancet 373:482-491. doi:10.1016/S0140-6736(08)61812-7

71. Jawed S, Kim B, Ottenhof T, Brown GM, Werstiuk ES, Niles LP (2007) Human melatonin MT1 receptor induction by valproic acid and its effects in combination with melatonin on MCF-7 breast cancer cell proliferation. Eur J Pharmacol 560:17-22. doi: 10.1016/j.ejphar.2007.01.022

72. Cinatl J Jr, Cinatl J, Driever PH, Kotchetkov R, Pouckova P, Kornhuber B, Schwabe D (1997) Sodium valproate inhibits in vivo growth of human neuroblastoma cells. Anticancer Drugs 8:958-963

73. Göttlicher M, Minucci S, Zhu P, Krämer OH, Schimpf A, Giavara S, Sleeman JP, Lo Coco F, Nervi C, Pelicci PG, Heinzel $\mathrm{T}$ (2001) Valproic acid defines a novel class of HDAC inhibitors inducing differentiation of transformed cells. EMBO J 20(24): 6969-6978. doi:10.1093/emboj/20.24.6969

74. Olsen CM, Meussen-Elholm ET, Røste LS, Taubøll E (2004) Antiepileptic drugs inhibit cell growth in the human breast cancer cell line MCF7. Mol Cell Endocrinol 213:173-179. doi:10.1016/ j.mce.2003.10.032

75. Jung M (2001) Inhibitors of histone deacetylase as new anticancer agents (Review). Curr Med Chem 8:1505-1511

76. Blaheta RA, Cinatl J Jr (2002) Anti-tumor mechanisms of valproate: a novel role for an old drug. Med Res Rev 22:492-511. doi:10.1002/med.10017

77. Wang YM, Jin BZ, Ai F, Duan CH, Lu YZ, Dong TF, Fu QL (2012) The efficacy and safety of melatonin in concurrent chemotherapy or radiotherapy for solid tumors: a meta-analysis of randomized controlled trials. Cancer Chemother Pharmacol 69:1213-1220. doi:10.1007/s00280-012-1828-8

78. Seely D, Wu P, Fritz H, Kennedy DA, Tsui T, Seely AJ, Mills E (2011) Melatonin as adjuvant cancer care with and without chemotherapy: a systematic review and meta-analysis of randomized trials. Integr Cancer Ther. doi:10.1177/153473541142 5484

79. Carillo-Vico A, Guerrero JM, Lardone PJ, Reiter RJ (2005) A review of the multiple actions of melatonin on the immune system. Endocrine 27(2):189-200. doi:10.1385/ENDO:27:2:189 